\title{
SERIAL STUDIES OF VIRUS MULTIPLICATION AND INTESTINAL DAMAGE IN GNOTOBIOTIC PIGLETS INFECTED WITH ROTAVIRUS
}

\author{
C. F. Crouch ANd G. N. Woode \\ Agricultural Research Council, Institute for Research on Animal Diseases, \\ Compton, Newbury, Berkshire RG16 ONN
}

\section{Plate XXXIV}

RotAVIRUSES cause diarrhoea in a wide range of mammals, and have been isolated from calves (Mebus et al., 1969; Turner, Caple and Craven, 1973; Woode et al., 1974), piglets (Woode et al., 1976), mice (Much and Zajac, 1972), foals (Flewett, Bryden and Davies, 1975), sheep (Snodgrass et al., 1976) and deer (Tzipori, Caple and Butler, 1976), as well as from children (Bishop et al., 1973; Flewett, Bryden and Davies, 1973). The SA11 virus isolated from a vervet monkey and the " $\mathrm{O}$ " (offal) virus isolated from cattle in a Johannesburg slaughter-house are also probably rotaviruses (Lecatsas, 1974). The virus attacks the epithelial cells of the small intestine (Mebus et al., 1971; Hall et al., 1976; Pearson and McNulty, 1977; Snodgrass, Angus and Gray, 1977), causing extensive atrophy of the villi, and can be detected by electronmicroscopy and immunofluorescence (Bishop et al., 1973; Stair et al., 1973; Davidson et al., 1975). The present paper describes the severity of the lesions in different parts of the small intestine of piglets and relates them to local virus production.

\section{MATERIALS AND METHODS}

Virus. A strain of pig rotavirus, SW20/21 (Woode et al., 1976), passaged eight times in gnotobiotic piglets, was prepared for experimental use as a bacterium-free faecal filtrate with an infectivity titre, in LLCMK2 cells, of $3.2 \times 10^{4}$ TCD50 per $10 \mu$ l. The inoculum was $0.5 \mathrm{ml}$

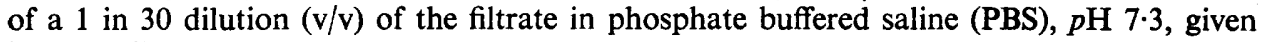
intranasally.

Animal experiments. Seven-day-old piglets were used for the experiments as they recover from rotavirus infection after 4-6 days; newborn piglets invariably die within 3 days. The piglets were weighed daily throughout the course of the experiments, before the first feed of each day.

The first experiment was made with ten 7-day-old gnotobiotic piglets (Tavernor et al., 1971); eight were infected intranasally with rotavirus (table; piglets number 5, 6, 10 and 14-18) and two were kept as uninfected controls (numbers 11 and 21). Infected animals were tested after $19 \mathrm{~h}, 22 \mathrm{~h}, 46 \mathrm{~h}, 65 \mathrm{~h}, 90 \mathrm{~h}, 116 \mathrm{~h}, 11$ days and 21 days and the controls after $18 \mathrm{~h}$ and 21 days. The animals were anaesthetised with chloroform and portions of small intestine were collected at five positions; position 1 was $5 \mathrm{~cm}$ above the ileo-caecal valve and positions 2-5 were at intervals of 50-60 cm along the intestine, reaching the duodenum at position 5 . At each position three portions of gut were tied off and removed, one for examination by immunofluorescence, one for histopathological examination, and one for the titration of virus

Received 22 Nov. 1977; accepted 30 Jan. 1978.

J. MED. MICROBIOL.-VOL. 11 (1978) 
in its luminal contents. The animals were then killed. The portions for immunofluorescence were snap frozen in a mixture of dry ice and acetone and stored at $-70^{\circ} \mathrm{C}$; those for histology were slightly dilated with $12 \%$ neutral buffered formalin before resection and were stored in formalin. The portions for virus titration were placed in a refrigerator $\left(4^{\circ} \mathrm{C}\right)$; within $24 \mathrm{~h}$ their external surfaces were washed thoroughly in double distilled water and blotted dry, and the contents were squeezed into bijou bottles. The contents were diluted 1 in 10 with PBS and centrifuged at 3000 r.p.m. for $15 \mathrm{~min}$; the supernate was filtered through membranes of pore size $0.45 \mu \mathrm{m}$ and stored at $4^{\circ} \mathrm{C}$. Virus infectivity titrations were carried out within 14 days.

In the second experiment, six 7-day-old gnotobiotic piglets from a litter of nine, were infected as in the previous experiment (table; piglets number 2, 3, 8, 9, 12 and 13); the remaining three were kept as uninfected controls (numbers 1,7 and 11). The infected piglets were examined after 13,14,37, 38, 61 and $62 \mathrm{~h}$ and the controls after 12,36 and $60 \mathrm{~h}$; chloroform was used to anaesthetise those sampled after 12,13,14 and $60 \mathrm{~h}$ and halothane (Fluothane, ICI Ltd) for the others. Portions of gut were collected and processed as before. However, in the case of piglet number 1 only four positions were sampled, namely those at $5,55,130$ and $205 \mathrm{~cm}$ from the ileo-caecal valve.

Examination by immunofluorescence. Rings of intestine were cut from the frozen portions, embedded in gelatin and frozen in liquid nitrogen. Sections, $6 \mu \mathrm{m}$ thick, were cut on a cryostat, fixed in acetone for $10 \mathrm{~min}$. and air dried. They were stained with a 1 in 20 dilution of a pig rotavirus antiserum conjugated with fluorescein isothiocyanate (kindly supplied by $\mathrm{Dr}$ E. H. Bohl, Ohio Agricultural Research and Development Centre, USA), in a moist chamber

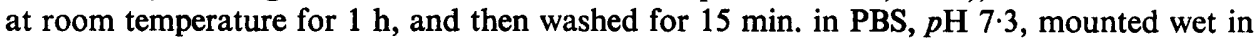
$80 \%$ glycerol and examined in a Leitz Ortholux Microscope with incident blue-light illumination.

Histopathological examination. Rings of fixed gut were dehydrated and embedded in paraffin wax, and sections $5 \mu \mathrm{m}$ thick were cut and stained with haematoxylin and eosin. The severity of the lesions in each of the five gut positions was estimated as the ratio, average villus length : average crypt length, calculated from measurements of the five longest complete villi and their associated crypts at each position, made with a light microscope equipped with a $\times 10$ objective and ocular micrometer (Hooper and Haelterman, 1969; Moon, Norman and Lambert, 1973; Thake, Moon and Lambert, 1973; Moon et al., 1975). No attempts were made to measure crypts associated with Peyer's patches.

Virus infectivity titrations. LLCMK2 cells were grown in the wells of Microtitre Plates (Sterilin Ltd) for $48 \mathrm{~h}$, in Eagle's minimal essential medium (MEM) containing $10 \%(\mathrm{v} / \mathrm{v})$ foetal calf serum; confluent monolayers were then re-fed with $100 \mu \mathrm{l}$ of MEM containing $2 \%$ (v/v) foetal calf serum. Serial 10-fold dilutions were made from the various gut-content filtrates in PBS, and $10 \mu \mathrm{l}$ of each dilution were added to each of 12 wells. The plates were sealed with adhesive tape and incubated for $40-42 \mathrm{~h}$ at $37^{\circ} \mathrm{C}$. After draining off the medium, the cell sheets were fixed for $10 \mathrm{~min}$. with a precooled $\left(-20^{\circ} \mathrm{C}\right)$ mixture of acetone and distilled water in the proportion $4: 1$, and then air dried at $37^{\circ} \mathrm{C}$. One drop of a 1 in 40 dilution of an anti-rotavirus antiserum prepared in calves was added to each well and the plates were incubated at room temperature for $1 \mathrm{~h}$ and then rinsed three times in PBS. One drop of a 1 in 40 dilution of fluorescein-conjugated rabbit anti-bovine gamma-globulin (Nordic Immunologicals Ltd) was added to each well, followed by incubation at room temperature for $1 \mathrm{~h}$ and further rinsing, three times, in PBS. The cell sheets were examined while still moist, through the floor of the wells of the inverted plates, with incident blue light in a Leitz Ortholux Microscope. Specific fluorescence was observed only in wells inoculated with material from infected piglets and never in the control wells that contained uninoculated monolayers; this showed that cross-contamination of wells either by free virus or by infected cells during the fixation and staining procedures was not a problem. Wells were scored positive or negative for the presence of fluorescing cells and the virus titre was calculated as TCD50 per $10 \mu \mathrm{l}$ by the Karber equation. This end-point method was found to be as sensitive as the more laborious technique of counting individual fluorescing cells and calculating the infectivity titre from the mean count of six wells infected with a single dilution of 
filtrate. Its reproducibility was confirmed by obtaining, in five separate tests, infectivity titres that differed by no more than $0 \cdot 25 \log _{10}$.

\section{RESULTS}

\section{Symptoms of infection}

All the infected piglets allowed to survive beyond $14 \mathrm{~h}$ developed typical symptoms within 19-24 h. These were anorexia, a look of depression and reluctance to move, soon followed by profuse diarrhoea. The anorexia persisted for $72 \mathrm{~h}$ and the diarrhoea, of decreasing severity, for about 10 days. The piglets began to lose weight about $24 \mathrm{~h}$ after infection, and, in those allowed to survive long enough, about $15 \%$ body weight was lost over a period of $24-36 \mathrm{~h}$; this was followed by rapid recovery of the lost weight by 3-5 days after infection.

\section{Immunofluorescence studies}

Specific staining was obtained in the villous epithelial cells of the mid (positions 2-4) and distal (position 1) parts of the small intestine and to a lesser extent of the proximal part (position 5) (table). Viral antigen was readily detectable at $19 \mathrm{~h}$ in over $80 \%$ of the cells in positions 3 and 4 , but only in scattered cells elsewhere (fig. 1). By $22 \mathrm{~h}$, however, about $70 \%$ of the cells in positions 1-4 gave strong fluorescence, the numbers then diminishing to less than $10 \%$ by $48 \mathrm{~h}$. At about $60 \mathrm{~h}$ there occurred a secondary increase in positions 3 and 4 , about $15 \%$ of the cells showing fluorescence; this increase occurred chiefly in the tips of the villi.

\section{Virus production}

By 13-14 h after infection small amounts of virus were present in the gut contents throughout positions 2-5 (table). No significant further increase in the amount of virus occurred in position 5 , but elsewhere the virus content rapidly increased to reach titres greater than $10^{6}$ TCD50 per $10 \mu \mathrm{l}$ by $19-22 \mathrm{~h}$, and then decreased over a period of about $24 \mathrm{~h}$ to about $10^{3}$ TCD50 per $10 \mu \mathrm{l}$. This low level was maintained for $c .48 \mathrm{~h}$ before the virus finally disappeared about 5 days after infection. However, a small secondary increase in titre occurred, particularly in the mid-region of the small intestine, over the period of 61-65 h.

\section{Histopathological studies}

Intestinal lesions, recorded as reductions in the ratio villus length : crypt length, were present mainly in the middle and distal parts of the small intestine and less strikingly in the duodenum (table). They were definitely established in positions $1-4$ by $36 \mathrm{~h}$, the ratio having dropped from the normal level of $>10: 1$ to $c .4: 1$. The epithelium was still essentially columnar, but in areas of greatest damage the brush border was ragged and even missing at the tips of some villi. The crypts were also noticeably enlarged. Maximal damage occurred at $46-65 \mathrm{~h}$, the villus length : crypt length ratio falling to $<2 \cdot 5: 1$ in the most severely affected regions. The villi were reduced in number and 
TABLE

(a) Virus infectivity titre of gut contents, (b) villus length: crypt length ratio, and (c) immunofuorescence of epithelial cells, at various levels of the small intestine, of piglets killed at intervals after infection with rotavirus

\begin{tabular}{|c|c|c|c|c|c|c|c|}
\hline \multirow{2}{*}{$\begin{array}{c}\text { Piglet } \\
\text { number }\end{array}$} & \multirow{2}{*}{$\begin{array}{c}\text { Interval } \\
\text { after } \\
\text { infection }\end{array}$} & \multirow{2}{*}{$\begin{array}{c}\text { Observation* } \\
\text { made }\end{array}$} & \multicolumn{5}{|c|}{ Results of observations* made on the small intestine at positions $\dagger$} \\
\hline & & & 1 & 2 & 3 & 4 & 5 \\
\hline $\begin{array}{c}1 \\
\text { (control) }\end{array}$ & $12 \mathrm{~h}$ & $\begin{array}{l}\mathrm{a} \\
\mathrm{b} \\
\mathrm{c}\end{array}$ & $\begin{array}{l}0 \\
19 \cdot 9(14 \cdot 6-26 \cdot 8) \\
-\end{array}$ & $\begin{array}{l}0 \\
15.8(13.4-17.9)\end{array}$ & $\begin{array}{l}0 \\
11 \cdot 7(10 \cdot 6-13 \cdot 1) \\
-\end{array}$ & $\begin{array}{l}\cdots \\
\cdots \\
\cdots\end{array}$ & $\begin{array}{l}0 \\
11 \cdot 8(11 \cdot 1-13 \cdot 9) \\
-\end{array}$ \\
\hline 2 & $13 \mathrm{~h}$ & $\begin{array}{l}\mathbf{a} \\
\mathbf{b} \\
\mathbf{c}\end{array}$ & $\begin{array}{l}0 \\
12 \cdot 3(8 \cdot 4-14 \cdot 3) \\
-\end{array}$ & $\begin{array}{l}5 \cdot 6 \\
14 \cdot 5(11 \cdot 5-19 \cdot 9) \\
-\end{array}$ & $\begin{array}{l}3.2 \times 10^{1} \\
12.9(10 \cdot 4-14 \cdot 7) \\
-\end{array}$ & $\begin{array}{l}5 \cdot 6 \\
9 \cdot 3(6 \cdot 7-11 \cdot 8) \\
-\end{array}$ & $\begin{array}{l}1 \cdot 2 \times 10^{3} \\
10 \cdot 9(8 \cdot 6-12 \cdot 3) \\
-\end{array}$ \\
\hline 3 & $14 \mathrm{~h}$ & $\begin{array}{l}\mathrm{a} \\
\mathrm{b} \\
\mathrm{c}\end{array}$ & $\begin{array}{l}0 \\
16 \cdot 7(15 \cdot 1-20 \cdot 4) \\
-\end{array}$ & $\begin{array}{l}7 \cdot 6 \\
14 \cdot 9(13 \cdot 8-16 \cdot 9) \\
-\end{array}$ & $\begin{array}{l}0 \\
13 \cdot 2(11 \cdot 7-15 \cdot 5) \\
-\end{array}$ & $\begin{array}{l}2.6 \times 101 \\
15.9(12.7-20.8) \\
-\end{array}$ & $\begin{array}{l}4 \cdot 6 \\
9 \cdot 9(7 \cdot 9-12 \cdot 8) \\
-\end{array}$ \\
\hline $\begin{array}{c}4 \\
\text { (control) }\end{array}$ & $18 \mathrm{~h}$ & $\begin{array}{l}\mathrm{a} \\
\mathrm{b} \\
\mathrm{c}\end{array}$ & $\begin{array}{l}0 \\
12 \cdot 4(7 \cdot 6-20 \cdot 8) \\
-\end{array}$ & $\begin{array}{l}\cdots \\
\cdots \\
\cdots\end{array}$ & $\begin{array}{l}0 \\
16 \cdot 1(12 \cdot 4-19 \cdot 4) \\
-\end{array}$ & $\begin{array}{l}\ldots \\
\cdots \\
\cdots\end{array}$ & $\begin{array}{l}0 \\
10 \cdot 9(9 \cdot 0-15 \cdot 3) \\
-\end{array}$ \\
\hline 5 & $19 \mathrm{~h}$ & $\begin{array}{l}\mathrm{a} \\
\mathrm{b} \\
\mathrm{c}\end{array}$ & $\begin{array}{l}1.4 \times 10^{5} \\
10 \cdot 4(6 \cdot 6-13 \cdot 8) \\
+\end{array}$ & $\begin{array}{l}2 \cdot 1 \times 10^{3} \\
11 \cdot 1(9 \cdot 1-12 \cdot 5) \\
+\end{array}$ & $\begin{array}{l}2 \cdot 1 \times 10^{6} \\
12 \cdot 9(11 \cdot 1-14 \cdot 7) \\
++\end{array}$ & $\begin{array}{l}1.0 \times 10^{6} \\
12 \cdot 3(8 \cdot 5-15 \cdot 3) \\
++\end{array}$ & $\begin{array}{l}3 \cdot 2 \times 10^{2} \\
14 \cdot 8(10 \cdot 8-18 \cdot 4) \\
+\end{array}$ \\
\hline 6 & $22 \mathrm{~h}$ & $\begin{array}{l}\mathrm{a} \\
\mathrm{b} \\
\mathrm{c}\end{array}$ & $\begin{array}{l}1 \cdot 4 \times 10^{6} \\
5 \cdot 6(4 \cdot 2-7 \cdot 8) \\
++\end{array}$ & $\begin{array}{l}1.5 \times 10^{6} \\
10 \cdot 4(6 \cdot 7-9 \cdot 1) \\
++\end{array}$ & $\begin{array}{l}5.6 \times 10^{5} \\
8 \cdot 5(7 \cdot 6-9 \cdot 1) \\
+\end{array}$ & $\begin{array}{l}1.2 \times 10^{6} \\
7.0(6 \cdot 2-8 \cdot 1) \\
++\end{array}$ & $\begin{array}{l}4 \cdot 6 \times 10^{2} \\
12 \cdot 4(11 \cdot 2-13 \cdot 7) \\
+\end{array}$ \\
\hline $\begin{array}{c}7 \\
\text { (control) }\end{array}$ & $36 \mathrm{~h}$ & $\begin{array}{l}a \\
b \\
c\end{array}$ & $\begin{array}{l}0 \\
15 \cdot 7(13 \cdot 7-17 \cdot 8)\end{array}$ & $\begin{array}{l}0 \\
24 \cdot 3 \\
-\end{array}$ & $\begin{array}{l}0 \\
16 \cdot 9(13 \cdot 0-19 \cdot 6) \\
-\end{array}$ & $\begin{array}{l}0 \\
11 \cdot 6(9 \cdot 0-14 \cdot 3) \\
-\end{array}$ & $\begin{array}{l}0 \\
11 \cdot 5(9 \cdot 0-13.9) \\
-\end{array}$ \\
\hline 8 & $37 \mathrm{~h}$ & $\begin{array}{l}\mathrm{a} \\
\mathrm{b} \\
\mathrm{c}\end{array}$ & $\begin{array}{l}1.9 \times 10^{5} \\
3 \cdot 5(2 \cdot 4-4 \cdot 6) \\
+\end{array}$ & $\begin{array}{l}1 \cdot 0 \times 10^{5} \\
4 \cdot 1(3 \cdot 4-5 \cdot 0) \\
+\end{array}$ & $\begin{array}{l}6.0 \times 10^{4} \\
6.9(6.0-8.5) \\
+\end{array}$ & $\begin{array}{l}1.8 \times 10^{5} \\
10.9(7.5-14.0) \\
+\end{array}$ & $\begin{array}{l}5.6 \times 10^{2} \\
9.9(8 \cdot 5-11 \cdot 4) \\
-\end{array}$ \\
\hline 9 & $38 \mathrm{~h}$ & $\begin{array}{l}\mathrm{a} \\
\mathrm{b} \\
\mathbf{c}\end{array}$ & $\begin{array}{l}8 \cdot 3 \times 10^{5} \\
3 \cdot 8(3 \cdot 2-4 \cdot 7) \\
+\end{array}$ & $\begin{array}{l}3.8 \times 10^{5} \\
4.0(3.6-4.5) \\
+\end{array}$ & $\begin{array}{l}2.1 \times 10^{5} \\
3.9(3 \cdot 2-4 \cdot 6) \\
+\end{array}$ & $\begin{array}{l}3 \cdot 1 \times 10^{3} \\
3 \cdot 3(2 \cdot 7-3 \cdot 8) \\
+\end{array}$ & $\begin{array}{l}4 \cdot 5 \times 10^{4} \\
6 \cdot 3(4 \cdot 8-8 \cdot 3) \\
+\quad\end{array}$ \\
\hline
\end{tabular}




\begin{tabular}{|c|c|c|c|c|c|c|c|}
\hline 10 & $46 \mathrm{~h}$ & $\begin{array}{l}\mathrm{a} \\
\mathrm{b} \\
\mathrm{c}\end{array}$ & $\begin{array}{l}3 \cdot 8 \times 10^{3} \\
2 \cdot 3(1 \cdot 8-2 \cdot 8) \\
+\end{array}$ & $\begin{array}{l}3 \cdot 9 \times 10^{4} \\
2 \cdot 1(1 \cdot 4-2 \cdot 5) \\
+\end{array}$ & $\begin{array}{l}3 \cdot 8 \times 10^{3} \\
3.4(2 \cdot 3-4 \cdot 4) \\
+\end{array}$ & $\begin{array}{l}4.5 \times 10^{2} \\
5 \cdot 3(4 \cdot 1-6 \cdot 6) \\
+\end{array}$ & $\begin{array}{l}1.0 \times 10^{3} \\
10.4(6.8-14.4) \\
+\end{array}$ \\
\hline $\begin{array}{c}11 \\
\text { (control) }\end{array}$ & $60 \mathrm{~h}$ & $\begin{array}{l}\mathrm{a} \\
\mathrm{b} \\
\mathrm{c}\end{array}$ & $\begin{array}{l}0 \\
19 \cdot 5(16 \cdot 6-25 \cdot 0) \\
-\end{array}$ & $\begin{array}{l}0 \\
22 \cdot 1(18 \cdot 8-26 \cdot 7) \\
-\end{array}$ & $\begin{array}{l}0 \\
17 \cdot 2(15 \cdot 2-19 \cdot 3) \\
-\end{array}$ & $\begin{array}{l}0 \\
13.9(12 \cdot 4-16.7)\end{array}$ & $\begin{array}{l}0_{13 \cdot 5}(11 \cdot 1-15 \cdot 0) \\
-\end{array}$ \\
\hline 12 & $61 \mathrm{~h}$ & $\begin{array}{l}\mathrm{a} \\
\mathrm{b} \\
\mathrm{c}\end{array}$ & $\begin{array}{l}1 \cdot 0 \times 10^{5} \\
2 \cdot 4(2 \cdot 1-2 \cdot 7) \\
+\end{array}$ & $\begin{array}{l}2.6 \times 10^{2} \\
2 \cdot 7(2 \cdot 5-2 \cdot 9) \\
+\end{array}$ & $\begin{array}{l}5 \cdot 6 \times 10^{3} \\
2 \cdot 5(2 \cdot 1-3 \cdot 3) \\
+\quad\end{array}$ & $\begin{array}{l}3.8 \times 10^{2} \\
3.0(2 \cdot 6-3.5) \\
+\quad\end{array}$ & $\begin{array}{l}3.5 \times 10^{2} \\
4.9(3.9-6 \cdot 3) \\
-\end{array}$ \\
\hline 13 & $62 \mathrm{~h}$ & $\begin{array}{l}\mathrm{a} \\
\mathrm{b} \\
\mathrm{c}\end{array}$ & $\begin{array}{l}7.6 \times 10^{3} \\
3.5(2.9-4.0) \\
+\end{array}$ & $\begin{array}{l}1.2 \times 10^{4} \\
2 \cdot 9(2 \cdot 6-3.5) \\
+\end{array}$ & $\begin{array}{l}\dddot{2} \cdot 9(2 \cdot 6-3 \cdot 6) \\
+\end{array}$ & $\begin{array}{l}2.6 \times 10^{4} \\
3.0(2 \cdot 3-3 \cdot 4) \\
+\end{array}$ & $\begin{array}{l}2.1 \times 10^{3} \\
5.0(3 \cdot 2-6 \cdot 3) \\
+\quad\end{array}$ \\
\hline 14 & $65 \mathrm{~h}$ & $\begin{array}{l}\mathrm{a} \\
\mathrm{b} \\
\mathrm{c}\end{array}$ & $\begin{array}{l}1 \cdot 2 \times 10^{4} \\
2 \cdot 5(2 \cdot 0-3 \cdot 3) \\
\ldots\end{array}$ & $\begin{array}{l}2 \cdot 1 \times 10^{2} \\
3.6(2 \cdot 8-5 \cdot 1) \\
\ldots\end{array}$ & $\begin{array}{l}8 \cdot 3 \times 10^{2} \\
2 \cdot 5(2 \cdot 1-3 \cdot 2) \\
\ldots\end{array}$ & $\begin{array}{l}5.6 \times 10^{4} \\
2.9(2 \cdot 6-3 \cdot 2) \\
\ldots\end{array}$ & $\begin{array}{l}5 \cdot 6 \times 10^{1} \\
6 \cdot 6(4 \cdot 6-7 \cdot 6) \\
\ldots\end{array}$ \\
\hline 15 & $90 \mathrm{~h}$ & $\begin{array}{l}\mathrm{a} \\
\mathrm{b} \\
\mathrm{c}\end{array}$ & $\begin{array}{l}1 \cdot 8 \times 10^{5} \\
4 \cdot 7(4 \cdot 4-5 \cdot 6) \\
\ldots\end{array}$ & $\begin{array}{l}\ldots \\
\cdots \\
\cdots\end{array}$ & $\begin{array}{l}8 \cdot 3 \times 10^{3} \\
3 \cdot 9(3 \cdot 0-5 \cdot 1) \\
\ldots\end{array}$ & $\begin{array}{l}\ldots \\
\cdots \\
\cdots\end{array}$ & $\begin{array}{l}0 \\
6 \cdot 2(4 \cdot 8-8 \cdot 2) \\
\ldots\end{array}$ \\
\hline 16 & $116 \mathrm{~h}$ & $\begin{array}{l}\mathrm{a} \\
\mathrm{b} \\
\mathrm{c}\end{array}$ & $\begin{array}{l}0 \\
4 \cdot 5(4 \cdot 1-4 \cdot 9) \\
\ldots\end{array}$ & $\begin{array}{l}\ldots \\
\cdots \\
\cdots\end{array}$ & $\begin{array}{l}0 \\
8 \cdot 8(7 \cdot 5-10 \cdot 1) \\
\ldots\end{array}$ & $\begin{array}{l}\ldots \\
\cdots \\
\cdots\end{array}$ & $\begin{array}{l}0 \\
6 \cdot 8(6 \cdot 2-8 \cdot 1) \\
\ldots\end{array}$ \\
\hline 17 & 11 days & $\begin{array}{l}\mathrm{a} \\
\mathrm{b} \\
\mathrm{c}\end{array}$ & $\begin{array}{l}0 \\
2 \cdot 8(1 \cdot 9-3 \cdot 3) \\
\ldots\end{array}$ & $\begin{array}{l}\ldots \\
\cdots \\
\cdots\end{array}$ & $\begin{array}{l}0 \\
3 \cdot 1(2 \cdot 5-3 \cdot 6) \\
\ldots\end{array}$ & $\begin{array}{l}\ldots \\
\cdots \\
\cdots\end{array}$ & $\begin{array}{l}0 \\
7 \cdot 1(5 \cdot 9-8 \cdot 4) \\
\ldots\end{array}$ \\
\hline 18 & 21 days & $\begin{array}{l}\mathrm{a} \\
\mathrm{b} \\
\mathrm{c}\end{array}$ & $\begin{array}{l}0 \\
3 \cdot 3(2 \cdot 2-4 \cdot 3) \\
\ldots\end{array}$ & $\begin{array}{l}\ldots \\
\cdots \\
\cdots\end{array}$ & $\begin{array}{l}0 \\
7 \cdot 0(5 \cdot 1-9 \cdot 8) \\
\ldots\end{array}$ & $\begin{array}{l}\cdots \\
\cdots \\
\cdots\end{array}$ & $\begin{array}{l}0 \\
5 \cdot 3(5 \cdot 0-5 \cdot 5) \\
\ldots\end{array}$ \\
\hline 19 & 21 days & $\begin{array}{l}\mathrm{a} \\
\mathrm{b} \\
\mathrm{c}\end{array}$ & $\begin{array}{l}0 \\
8 \cdot 6(6 \cdot 8-10 \cdot 8) \\
\ldots\end{array}$ & $\begin{array}{l}\cdots \\
\cdots \\
\cdots\end{array}$ & $\begin{array}{l}0 \\
8 \cdot 3(7 \cdot 2-10 \cdot 9) \\
\ldots\end{array}$ & $\begin{array}{l}\cdots \\
\cdots \\
\cdots\end{array}$ & $\begin{array}{l}0 \\
9 \cdot 4(7 \cdot 8-11 \cdot 7) \\
\ldots\end{array}$ \\
\hline
\end{tabular}

$* a=$ Virus infectivity titre (TCD50 per 10 $\mu$ l); $b=$ villus length : crypt length ratio (figures in parenthesis represent the ranges of values obtained); $\mathrm{c}=$ immunofluorescence in cells (percentage of cells involved: $++=60-80 \% ;+=5-30 \% ;-=0 \% ; \ldots=$ not done).

+ Intestinal positions 1-5 are defined under Materials and methods. 
severely stunted and some fusion of villi was noted. Most of the epithelial cells: were now either cuboidal or squamous and desquamated cells were present in the lumen of the gut. Repair of villous structure began at about $65 \mathrm{~h}$, and by $90 \mathrm{~h}$ the villi, although they were still stunted, were again lined mainly with columnar epithelial cells. By 5 days the villi throughout the small intestine were still short but otherwise apparently normal. However, the villus length : crypt length ratio was still significantly less than in the uninfected control piglets, even after 3 weeks. In the control animals it was noticeable that the villus length : crypt length ratio varied along the length of the gut and also decreased with the age of the piglet, as previously reported by Moon et al. (1973). Fig. 2 illustrates the correlation between virus production and the histological changes that occurred during the course of the infection; the illustration takes account both of intracellular virus as shown by immunofluorescence, and of virus released into the gut lumen as shown by direct titration.
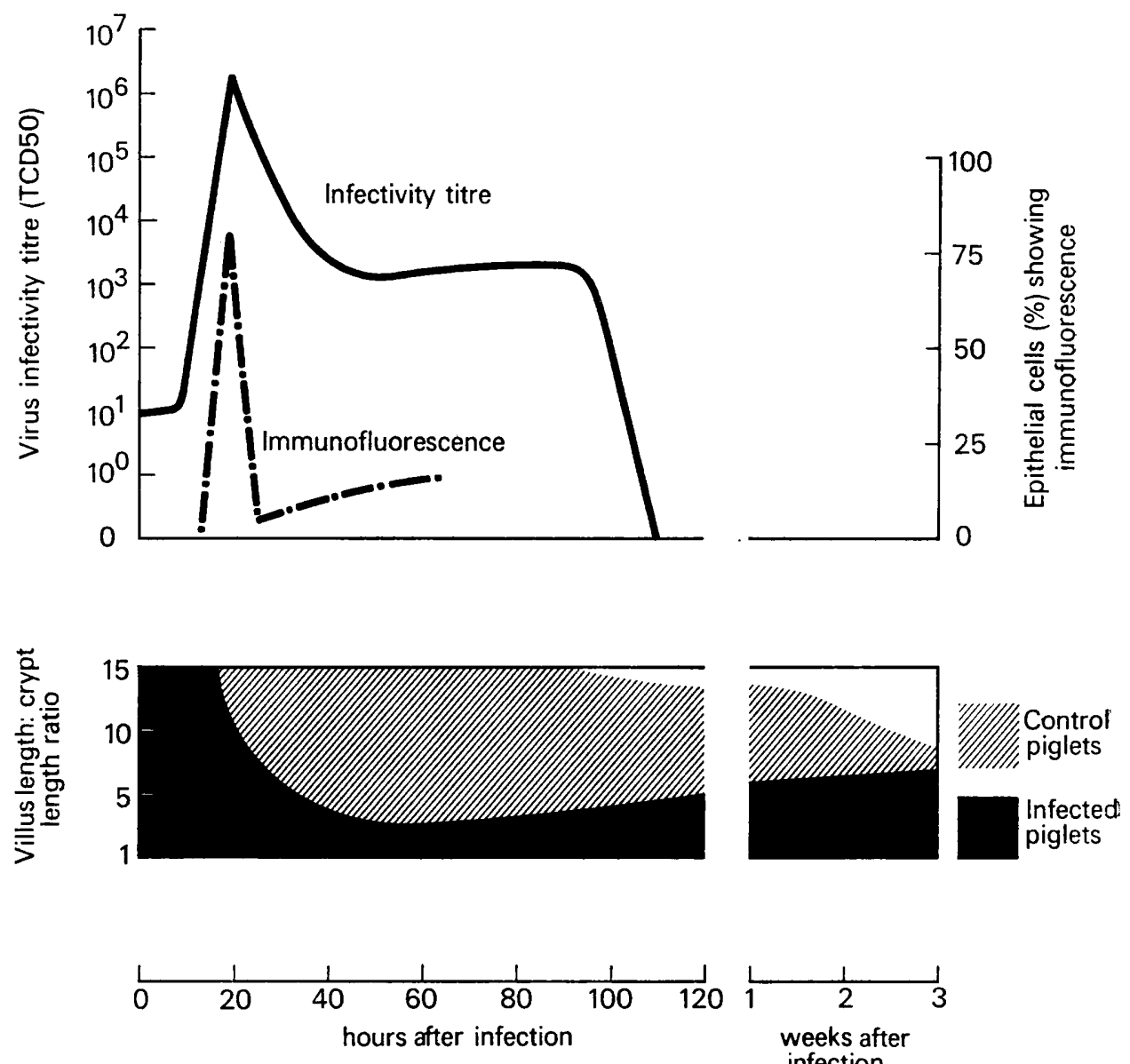

FIG. 2.-Correlation of virus infectivity titre of gut contents, involvement of epithelial cells as determined by immunofluorescence, and changes in the villus length : crypt length ratio, in the mid small-intestinal region, during the course of rotavirus infection. 


\section{Discussion}

From previous observations we had already recognised variation in the clinical severity of rotavirus infection among piglets of the same age. Thus although three piglets, in a single isolator and given the same dose of virus, all developed diarrhoea, one showed normal weight gain, one failed to gain weight, and one lost $c .15 \%$ of body weight. We attempted, in the current studies, to minimise such variation by limiting the animals in each experiment to those from a single litter. This, of course, introduced severe restrictions on the number of animals per test, especially on the number of controls. However, the variation in body weight response over the two experiments was low and allowed us to integrate with confidence the results from the two experiments.

The pathogenesis of rotavirus infection has been described in calves (Mebus et al., 1971), piglets (Hall et al., 1976; Pearson and McNulty, 1977) and lambs (Snodgrass et al., 1977), but these studies did not correlate the severity of the intestinal lesions with virus production over the course of the infection. There is a possible criticism of the present attempt to study the virus content of particular sections of gut, namely that peristalsis caused mixing of virus along the gut. However, the correlation found between the number of fluorescing villous-epithelial cells and the amount of virus in the lumen, in the various parts of the gut, showed that peristaltic movement of virus along the gut was not a significant problem.

Virus replication, studied by immunofluorescent staining, appeared to occur only in the epithelial cells of the villi. Presumably these cells lost functional activity very quickly after infection, and the resulting loss of absorption gave rise to diarrhoea before the appearance of histopathological changes. The crypt cells are responsible for the regeneration of intestinal mucosa and their resistance to rotavirus infection is obviously important for recovery. Initial hyperplasia of the cells lining the crypts occurs in an effort to maintain normal villous structure in the face of massive epithelial desquamation, but inability to replace the lost cells fast enough results in atrophy of the villus. The marked drop in body weight following infection was obviously the result of the gut damage, but as 7-day-old piglets, unlike newborn piglets, are readily able to cope with the physiological problems caused by damage to the absorptive layer of epithelium, the lost weight was soon restored. Control of the virus infection and regeneration of the villous epithelium led to amelioration of the diarrhoea but some looseness of the faeces persisted until about the 10th day, perhaps because of functional immaturity of the newly regenerated epithelium and of residual virus infection. It is interesting that, during the early stage of infection, fluorescing cells were scattered all over the surface of the villi, but later, once recovery had started, they were restricted to the tips of the villi. This finding has also been reported by Mebus et al. (1971) and Snodgrass et al. (1977); it may be related to regeneration of healthy cells from the crypt upwards along the villus, and may explain the secondary burst of virus replication $60-65 \mathrm{~h}$ after infection.

Recovery from rotavirus infection appeared to be biphasic (fig. 2). The first phase started about $22 \mathrm{~h}$ after initial infection and resulted in a 1000-fold 
reduction in viral content of the lumen of the gut. Its extremely early onset suggested that it was non-immune in nature. It is likely to have been due to the loss of viral receptor sites (Holmes et al., 1976), following extensive destruction of the villous epithelium and its replacement by undifferentiated cells, and to the production of interferon and other non-specific inhibitors. Rotavirus has been shown to stimulate interferon production in vitro (Welch and Twiehaus, 1973) and viral inhibitors have been detected in the intestinal mucosa of healthy mice (Piazza et al., 1967). The second phase (fig. 2) came into operation at about $90 \mathrm{~h}$ and led to final elimination of the virus. This is more likely to have been due to an antibody response. Thus, Blandford and Heath (1972) demonstrated antibody in the lungs of Sendai virus-infected mice as early as the 3rd day of infection, and Mebus (1975) showed the disappearance of virus from ThiryVella loops of coronavirus-infected calves 5-6 days after infection, and the presence of antibody in the loops 7 days after infection.

The more limited involvement of the proximal region of the small intestine in the infection may have been the result of differences in cell differentiation in different parts of the small intestine (Baintner and Veress, 1967), and possibly to greater abundance in the upper part of the gut of the inhibitory agents mentioned above.

In terms of pathogenesis and course, rotavirus infection in piglets resembled transmissible gastroenteritis (Pensaert, Haelterman and Burnstein, 1970); the lower mortality and less severe diarrhoea in rotavirus infection may be because the intestinal lesions spread more slowly and are less severe than in transmissible gastroenteritis, giving the piglets a better chance to adjust to the associated physiological disturbances.

\section{SUMMARY}

A serial study of rotavirus infection in gnotobiotic piglets is described. They were infected when 7 days old and the course of infection was followed for 21 days, by immunofluorescence and histological examinations of the intestinal epithelium and by titration of the virus content of the gut lumen. There appeared to be two stages of recovery of the intestinal wall, the earlier stage involving non-immune mechanisms and the later involving antibody.

We wish to thank Mr M. Dennis for the supply of gnotobiotic piglets and Mr P. Dennis for the histological sections. One of us (C. F. C.) was supported by a grant from the Agricultural Research Council.

\section{REFERENCES}

BAINTNER, K. AND Veress, B. 1967. Longitudinal differentiation of the small intestine. Nature, Lond., 215, 774.

Bishop, R. F., Davidson, G. P., Holmes, I. H. AND Ruck, B. J. 1973. Virus particles in epithelial cells of duodenal mucosa from children with acute non-bacterial gastroenteritis. Lancet, $2,1281$.

BlandFoRd, G. AND HEATH, R. B. 1972. Studies on the immune response and pathogenesis of Sendai virus infection of mice. I. The fate of viral antigens. Immunology, 22, 637.

Davidson, G. P., Goller, I., Bishop, R. F., Townley, R. R. W., Holmes, I. H. AND Ruck, B. J. 1975. Immunofluorescence in duodenal mucosa of children with acute enteritis due to a new virus. J. clin. Path., 28, 263. 


\section{ROTAVIRUS INFECTION IN PIGLETS}

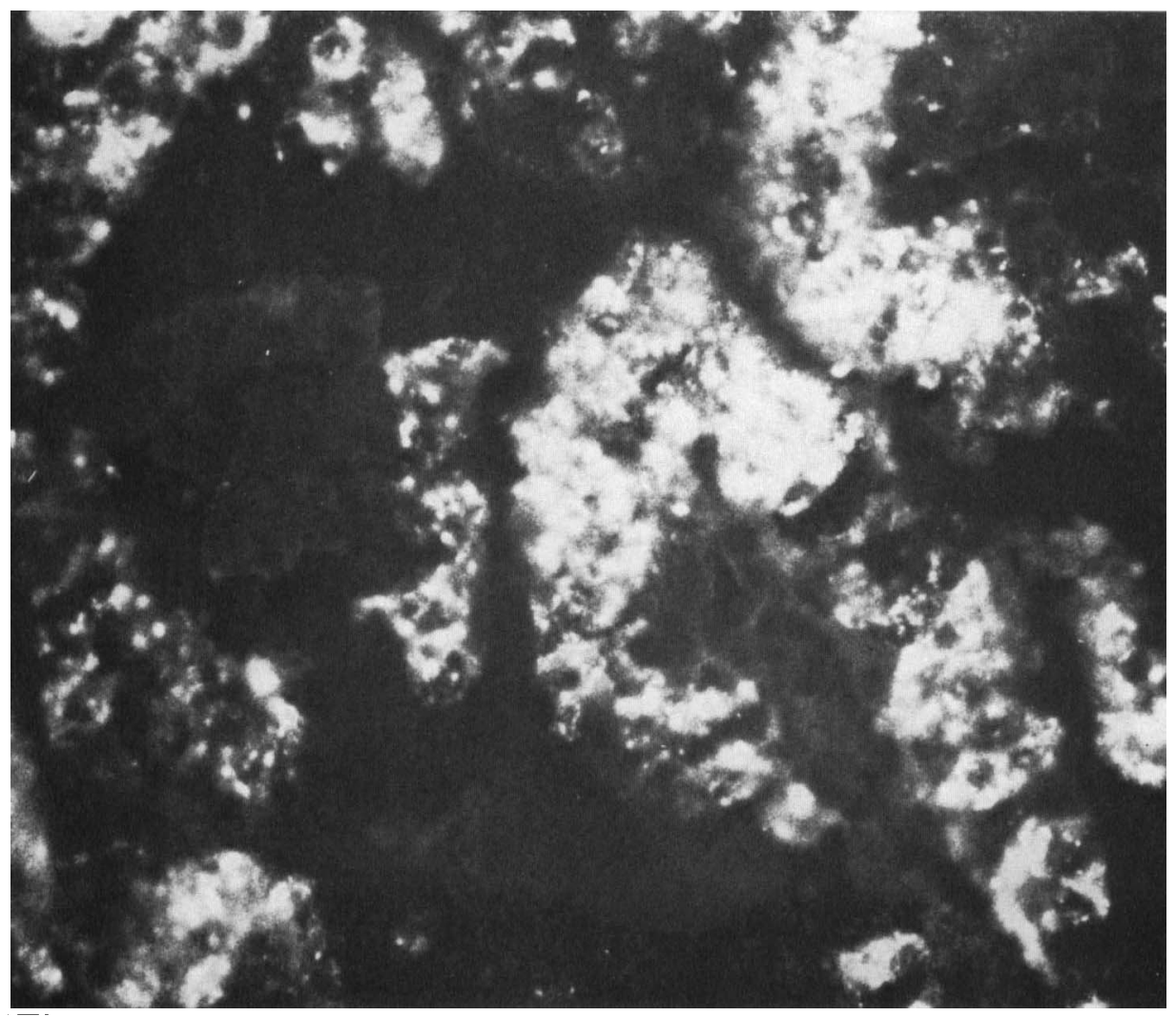

FIG. 1.-Tip of a villus in the mid-region of the small intestine showing extensive involvement of epithelial cells $19 \mathrm{~h}$ after rotavirus infection. Immunofluorescence. $\times 250$. 
Flewett, T. H., Bryden, A. S. and Davies, H. 1973. Virus particles in gastroenteritis. Lancet, 2, 1497.

Flewett, T. H., Bryden, A. S. And Davies, H. 1975. Virus diarrhoea in foals and other animals. Vet. Rec., 96, 477.

Hall, G. A., Bridger, J. C., Chandler, R. L. and Woode, G. N. 1976. Gnotobiotic piglets experimentally infected with neonatal calf diarrhoea reovirus-like agent (rotavirus). Vet. Path., 13, 197.

Holmes, I. H., Rodger, S. M., Schnagl, R. D., Ruck, B. J., Gust, I. D., Bishop, R. F. AND BARNES, G. L. 1976. Is lactase the receptor and uncoating enzyme for infantile enteritis (rota) viruses? Lancet, 1, 1387.

HoOper, B. E. AND Haelterman, E. O. 1969. Lesions of the gastrointestinal tract of pigs infected with transmissible gastroenteritis. Can. J. comp. Med., 33, 29.

LeCATSAS, G. 1974. Virus particles in acute gastroenteritis. Lancet, $2,524$.

Mebus, C. A. 1975. Coronavirus enteritis in calves. In Abstracts of Proc. 3rd Int. Congr. Virol., Madrid, p. 70.

Mebus, C. A., Stair, E. L., Underdahl, N. R. and Twiehaus, M. J. 1971. Pathology of neonatal calf diarrhea induced by a reo-like virus. Vet. Path. 8, 490.

Mebus, C. A., Underdahl, N. R., Rhodes, M. B. and Twiehaus, M. J. 1969. Calf diarrhoea (scours) reproduced with a virus from a field outbreak. Nebraska Agric. Exp. Stat. Bull., 233, 1 .

Moon, H. W., Kemeny, L. J., Lambert, G., Stark, S. L. and Booth, G. D. 1975. Age dependent resistance to transmissible gastroenteritis of swine. III. Effects of epithelial cell kinetics on coronavirus production and on atrophy of intestinal villi. Vet. Path., 12, 434.

Moon, H. W., Norman, J. O. and Lambert, G. 1973. Age dependent resistance to transmissible gastroenteritis of swine. I. Clinical signs and some mucosal dimensions in small intestine. Can. J. comp. Med., 37, 157.

MuCH, D. H. AND ZAJAC, I. 1972. Purification and characterization of epizootic diarrhea of infant mice virus. Infect. Immun., 6, 1019.

Pearson, G. R. AND McNulty, M. S. 1977. Pathological changes in the small intestine of neonatal pigs infected with a pig reovirus-like agent (rotavirus). J. comp. Path., 87, 363.

Pensaert, M., Haelterman, E. O. and Burnstein, T. 1970. Transmissible gastroenteritis of swine: virus-intestinal cell interactions. I. Immunofluorescence, histopathology and virus production in the small intestine through the course of infection. Arch. ges. Virusforsch., 31, 321.

Piazza, M., Pane, G., Piciotto, L. And Lombardi, D. 1967. Effect on the infectivity of various viruses by the intestinal factor of normal mice which inactivates murine hepatitis virus. Nature, Lond., 213, 293.

Snodgrass, D. R., ANGus, K. W. and Gray, E. W. 1977. Rotavirus infection in lambs: pathogenesis and pathology. 1978. Archs Virol., 55, 263.

Snodgrass, D. R., Smith, W., Gray, E. W. ANd Herring, J. A. 1976. A rotavirus in lambs with diarrhoea. Res. vet. Sci., $20,113$.

Stair, E. L., Mebus, C. A., Twiehaus, M. J. and Underdahl, N. R. 1973. Neonatal calf diarrhea: electron microscopy of intestines infected with a reovirus-like agent. Vet. Path., 10, 155.

Tavernor, W. D., Trexler, P. C., Vaughan, L. C., CoX, J. E. and Jones, D. G. C. 1971. The production of gnotobiotic piglets and calves by hysterotomy under general anaesthesia. Vet. Rec., 88, 10.

Thake, D. C., Moon, H. W. and Lambert, G. 1973. Epithelial cell dynamics in transmissible gastroenteritis of neonatal pigs. Vet. Path., 10, 330.

Turner, A. J., Caple, I. W. And Craven, J. A. 1973. Demonstration of virus particles in intestinal contents of calves with diarrhoea. Aust. vet. J., 49, 544.

TzIPORI, S., CAPLE, I. W. AND BUTLER, R. 1976. Isolation of a rotavirus from deer. Vet. Rec., 99, 398. 
Welch, A. B. AND Twiehaus, M. J. 1973. Cell culture studies of a neonatal calf diarrhea virus. Can. J. comp. Med., 37, 287.

Woode, G. N., Bridger, J. C., Hall, G. AND Dennis, M. J. 1974. The isolation of a reovirus-like agent associated with diarrhoea, in colostrum-deprived calves, in Great Britain. Res. vet. Sci., 16, 102.

Woode, G. N., Bridger, J., Hall, G. A., Jones, J. M. and Jackson, G. 1976. The isolation of reovirus-like agents (rotaviruses) from acute gastroenteritis of piglets. $J$. med. Microbiol., 9, 203. 